\title{
The Impact of Celebrity Endorsement on Consumer Buying Behavior
}

\author{
Humaira Mansoor Malik \\ Department of Management Sciences \\ Islamia University Bahawalpur \\ Muhammad Mehtab Qureshi \\ Department of Management Sciences \\ Islamia University Bahawalpur
}

\begin{abstract}
The purpose of this study is to explore the impact of celebrity endorsement on consumer's buying intentions. This study concentrated on discovering the thoughts of Pakistani customers about celebrity endorsement by analyzing the different characteristics of the celebrity endorsement with respect to consumer's buying intentions. In this study we reviewed the former literature present on the topic of celebrity endorsement. That gives clear perception of different important prospects regarding this topic. In order to discover the impact of different attributes of celebrity on consumer buying behavior quantitative approach is applied. The data has been collected from 150 respondents with the help of structured questionnaire and analyzed by using software SPSS. It was find that some aspects of celerity endorsement like gender, attractiveness, credibility, endorser type \& multiple celerity endorsement proved to be effective with respect to buying intentions while multiple product endorsement has negative relationship with consumer buying behavior. In the end the study proves that the overall impact of celebrity endorsement on consumer's buying intentions is positive.
\end{abstract}

Keywords: Celebrity endorsement, Celebrity endorser, Purchase intentions, Consumer buying behavior, Celebrity endorsement in Pakistan.

\section{INTRODUCTION}

Today the world has become more competitive and consumers are opened to thousands of expressions and pictures in magazines, newspapers and on billboards, websites, radio and television. Marketers try hard to capture a small portion of an individual's time in order to let him/her know of the wonderful and unique characteristics of the product or brand. Most of the people daily experience the constant bombardment of advertisements by the media so ultimately people become emotionless towards all the advertisement practices. Its marketers and advertisers test to discover a knob that will grasp the consumer's consideration. Celebrities are the knobs that can grasp the customer's attention easily. In today's modern era, while looking through the magazines and newspapers or even watching television, people most likely to neglect all the commercials and advertisements. Despite of the fact, the charm and enchant of the celebrity is rarely ignored. The effect of celebrity endorsement on advertisement and on the brand is of huge importance. For this process businesses and firms usually appoint celebrities from a specific area in order to give them a chance to be a part of advertisement campaign. In order to motivate a consumer to consider a particular brand from a diverse series of brands, the marketing attributes and imageries of a brand are complemented with the celebrity. 
With the conviction that celebrities are influential spokesperson for their brands, advertisers devotes the huge volume of money on celebrity endorsement agreements every year. These days' different companies are using celebrities in their advertisements with the expectation that by using celebrities they can achieve a distinctive place in consumer's mind.

According to Oxford dictionary, celebrity means "A famous person". A person who is outshined in his/her area of expertise. It could be in the domain of sports, cinema, theatre, social life politics or science anything but with some unique outcome (Giridhar, 2012). People who celebrated by an enormous cluster of people are known as celebrities. Some illustrations of the characteristics include attractiveness, astonishing way of life or exceptional expertise. These celebrities usually vary from average community and relish high amount of recognition by people are also some usual attributes of them. The word celebrity states a person familiar by the people (actor, sports figure, entertainer, etc.) due to their accomplishments in the fields besides the product they have endorsed (Friedman and Friedman, 1979).

A conduct of brand message in which a celebrity performs as the brand's representative and verifies the brand's assertion and position the brand by prolonging his/her personality fame, standing in the society or skills in the area to the brand (Roll, 2006).

McCracken's (1989) definition of a celebrity endorser is, "Any individual who enjoys public recognition and who use this recognition on behalf of a consumer good by appearing with it in an advertisements, is useful, because when celebrities are depicted in advertisements, they bring their own culturally related meanings, thereto, irrespective of the required promotional role". Companies favors celebrities of various areas in India, for example Cricketers, Bollywood celebrities and other sports persons to endorse their brands are increasing (Dengra, nd).

\section{OBJECTIVE OF THE STUDY}

As explained before that there is a lot of academic literature available on the topic of celebrity endorsement in other different countries. There are also some researches available those oppose the idea of impact of celebrity endorsement on consumer buying intentions. Therefore the key objective of this study is to examine the relationship of endorser's gender, attractiveness, credibility, type (celebrity vs non-celebrity) as well as multiple endorsements and multiple product endorsement on customers buying intentions. Moreover, we are living in an era where use of celebrity endorsers by brands is increasing day by day. But unfortunately there is not much work has been done in Pakistani market, and particularly no data is available related to buying intentions of Pakistani consumers. As most of the advertisements in Pakistan features celebrities as endorsers in order to promote their products.

This study emphasizes on different aspects of celebrity endorsement that attempts to make it clear and enhance further information regarding this topic. Following are the main objectives of this study:

- To discover and investigate the current state of consumer's perception about celebrity endorsements.

- To understand the effectiveness of celebrity endorsement.

- To identify the key factors which may influence consumer's buying behavior through celebrity endorsements.

- To examine the impact of celebrity endorsements on consumer's purchase intentions.

- To draw a meaningful conclusion from the study. 


\section{LITERATURE REVIEW}

Marketing tends to adopt new and different modes of promoting their product, and marketers are in search of different and unique means to attain the whole new level of active and persuasive advertisements and promotion. Celebrity endorsement is one of these means to persuade the consumer. Today the marketers recognize it properly that celebrities play a significant role in order to make the Ads more compelling and convincing (CHOI and Rifon, 2007).

According to Schlecht (2003) term 'celebrity' can be defined as,

"Celebrities are people who enjoy public recognition by a large share of certain group of people".

And Kurzman et al, (2007) states:

"Celebrity is an omnipresent feature of society, blazing lasting impressions in the memories of all who cross its path".

Danieal.J.Boortish defines:

"A sign of a celebrity is that his name is often worth more than his services".

Celebrities are individuals who relish public gratitude and acknowledgement, and who frequently possess unique traits like Charm and Credibility (McCracken, 1889; Silvera and Austad, 2004).

The term 'Celebrity' denotes a person who is popular among people such as actors, sportsperson, entertainers and others who have accomplishments in their respective fields besides the product they endorsed (Friedman and Friedman, 1979).

McCracken (1989) defined celebrity endorser as:

"Any individual who enjoys public recognition and who uses this recognition on behalf of a consumer good by appearing with it in an advertisement".

While Stafford et al, (2003) gives a definition of endorsers as,

"A famous person who uses public recognition to recommend or co-present with a product in an ad".

During all these years, many researchers have proposed theories in order to know the means that makes celebrity endorsement productive and fruitful. Along with several theories proposed, many of them also studies all the elements that be a factor in celebrity endorsements and what kind of impression they have on buyers conduct (Esangbedo, 2011). Celebrity endorsement is been assumed to be an "omnipresent attribute of today's advance marketing" (McCracken, 1989). Advertisers utilize celebrity to persuade the buying choice of their customers and it gives them great edge for revenue or high yields of sales (Raval and Tanna, 2014).

Sellers spend huge volume of money yearly on celebrity endorsement agreements built on faith that celebrities are great representative for their product or brands. Currently Celebrity endorsement is considered as a billion dollar industry (Katyal, 2007). Different companies endorse celebrities in faith that by utilizing them they can achieve distinctive and significant place in the minds of customers (Kambitsis et al, 2002). Celebrity endorsement is progressively 
being utilized by different companies irrespective of the product category (Temperley \& Tangen, 2006).

Mostly brands are living their life without using a celebrity or brand personality. Honestly, solely dependence on brand will only give disappointment as brand itself could never talk, walk or even get snapped. But if you utilize a celebrity in an effective manner then it could give the product and company the ultimate and instantaneous glamor, oomph and ambition (Mukherjee, 2009). D.

Reeder (Greenlight L.A) said:

"People's fascination with celebrities isn't going away. The use of celebrities is here to stay. But in what form is the open question".

According to Reynolds (2000) celebrity endorsement can enhance the charm \& enchant of a brand. When celebrities are used in an effective manner they have the ability to play worthful role in improving brand's competitive perspective and increasing brand equity (Alperstein, 1991). The application of celebrity endorsement is so productive that it has now become an industry. There are advertising businesses that are specialize in assessing the stock value of the celebrities and assisting brands couple their products with the suitable celebrity (Esangedo, 2011). While developing of promotional program, it's compulsory the plan adopted should have significant concentration on unique and different message regarding the product in order to persuade the positive attitude and improved buying behavior towards brand (Lafferty \& Goldsmith, 2004).

The idea of customer behavior is of acute importance in the promotion of goods and services, because customer's behavior fluctuate a lot. Hence a clear realization of customer's conduct help companies in discovering what matters to the customers, and proposes the significant effects on customers purchase decisions. This helps sellers to supply goods \& services according to the need of the target market (Dzisah \& Ocloo, 2013). Loudon \& Bitta (1994) defined consumer behavior as;

"The decision process and physical activity individuals engage in when evaluating, inquiring, using or disposing of goods and services".

Because of their popularity, celebrities not only gains attention but also get high recall rates for marketing messages in today's immensely chaotic atmosphere (Kasana and Chaudhary, 2014). Customers purchase conduct has always been a significant part of the literature study of effect of advertising with respect to its usefulness (Aizen, 2002). Mostly customers buying behavior is determined by likes and dislikes of customers regarding the marketing of the product which has been advertised (Smith et al, 2002). According to Aaker (1996) Brand face and celebrity endorsement is seen as the fundamental component of effective marketing.

\section{GENDER}

Gender denoted the traits that distinguish males and females (Phang and De Run, 2007).The suitable and acceptable conducts for both male and female differs in every society with their own prospects.

There is hardly any research in Pakistan regarding "gender of celebrity endorser and consumer's gender". So it provided a room for research to focus on the possible gender differences among the perception and selection of celebrity endorsers. But in other countries there has been some work done on this topic. 
Some old studies have discovered that there are two contradictory thoughts regarding the association between endorser's gender and consumer's gender. First one says that customer's behavior towards product doesn't meaningfully effects by endorser's gender (Freiden, 1984). And second thought says that customer's behavior for products drastically impacts by endorser's gender (Lafferty et al, 2002).

Frieden (1984) studied and found that customer's behavior regarding television Ads didn't considerably impacted by endorser's gender. While Crasky and Zuckerman (1991) found that there is no relationship between the purchase intentions of a buyer and gender of the endorser. In contrast, Debevee \& Kertian (1984) discovered that endorser and the customer have relationship.

Both genders but especially male's behavior and conducts significantly impacts by attractive female models than attractive male models. Klaus and Bailey (2008) identified that female celebrity endorsers and male celebrity endorsers receives different customer reaction, and the Ads which have female celebrities proved more promising than male celebrities.

As compared to male celebrities, female celebrities are more credible (Goldman, 1995; St. James and Swartz, 2004). Caballero \& Pride (1984) explored the gender of the celebrity used in a direct mail advertisement impacts the consumer buying behavior regarding the product. They found that customers buying intentions raised if the celebrity used in a snap shot is highly attractive female rather than an unattractive female, male or even an attractive male.

Alternatively, Tom et al, (1992) questioned the television audience to distinguish the brands of products like dishwashing products, beer and toilet tissue, related to different celebrities communicating through television Ads. And the outcome was that female viewers are more influenced by female endorsers and males are influenced by male spokesperson. This is because of the possibility that for female customers, female endorsers have more referent command as well as male endorsers have more authority to male customers. Even if female defendants didn't show a fondness for female celebrity endorsers or male celebrities, but male plaintiffs would be touched by male celebrities 2.51 times more than by female celebrity endorsers in buying decision.

Baker and Churchill (1977) finished as that customers buying intentions towards an advertisement presenting a celebrity of opposite sex, is greater than advertisement with endorser of similar sex. Jain and Patel (nd) claimed that gender of endorser only matters when the type of the product they are endorsed is appropriate to them and that Ads regarding banking, financial services \& clothing are more appropriate for male endorsers, on the other hand female endorsers are more appropriate for cosmetics, soaps and food items.

Now it's clear that the results with respect to gender or cross gender relations between celebrities and consumers are diverse, so we have to find the results through testing.

H1: Endorser's gender has a relation with consumers purchase intentions.

\section{ATTRACTIVENESS}

"Beauty is a greater recommendation than any letter of introduction"_ Aristotle.

Patzer (1985) stated that:

"Physical attractiveness is an informal cue involves effects that are subtle, pervasive and inescapable". 
He supported the idea of using attractive celebrities in Ads than average looking celebrities. He said consumers endeavor to boost their appeal and charm and respond certainly to the celebrities who resembles them (Erdogen, 1999). Attractiveness was a degree that provoke the attention of many people. It is just not restricted to the size of the body but it consists of all of physical characteristics for example hair color, facial features and physical appearance (Piu Yi \& Priscilla, 2012).

Attractiveness also impacts consumer's attitudes because they want to look attractive, stylish and glamorous like celebrities. For example if a young girl finds Katrina Kaif attractive and beautiful, so she (Katrina) can influence the consumer's behavior towards the brands she endorses. Because those girls believe that it will assist them in looking attractive too.

Research has proved that physically attractive endorsers are more influential in order to alter beliefs (Baker and Churchill 1977; Chaiken 1979; Debevee and Keman 1984) and creating buying intentions (Friedman et al, 1976; Petroshius and Crocker 1989; Petty and Cacioppo 1980) than their unattractive equivalents. The study of many researchers demonstrates that exterior and physical beauty is an important factor which helps in determining the effectiveness of the endorser (Baker, Churchill et al, 1977; Joseph 1982; Kahle and Hamer, 1985; Winham \& Hampl, 2008). But contrary to this Bower and Landerth (2001) explains that the endorsers which are more attractive are not that much good for advertising. Attractiveness has many ranks which could not determine easily, it's difficult to define attractiveness through one aspect (Cabalero \& Solomon, 1984). The attractiveness and outer look is not the only factor that counts but the non-physical attributes also matters in the effectiveness of endorser like achievements in sports, insight and intelligence (Kamins, 1990; Sliburyte, 2009) relating to the cultural group of customer (Deshponde`\& Stayman, 1994).

In source attractiveness model it is stated that effectiveness of an advertisement is determined by the similarity, awareness and fondness of celebrity (McGuire, 1985). Attractiveness not only means physical attractiveness but it includes the whole lifestyle of the celebrity, different aspects of his personality (Ahmed, Mir \& Farooq, 2012). If customers think that endorser is similar to them, associated and they are also like that endorser, the celebrity becomes more beautiful for the customers (Amos, Holmes and Strutton, 2008). Hence it is proved that celebrities raise attitudes towards advertising, but nothing can be explained yet that if they improve buying intentions.

H2: Endorser's attractiveness has a relation with customer purchase intentions.

\section{Credibility}

Source credibility is defined as;

“Communicator's positive characteristics that subsequently influence the receiver's evaluation of the message" (Hovland and Weiss, 1951, Ohanion, 1991).

According to Ohanion (1990):

Source credibility was the degree to which the receiver would believe the source has certain degree of relevant knowledge or expertise and they choose to believe the information offered by the source".

In an advertisement source credibility simply reflects the endorser's credibility (Aronson, Turner and Carlsmith, 1963). Credibility is taken as a significant element that can impact 
customer's buying behavior and their approach towards advertising (Lutz, Mackenzie and Belch, 1983).

Endorser's credibility is the most commonly used technique in marketing to influence customer buying behavior (Lafferty \& Goldsmith, 1999).

In 1990 Ohanian proposed a model, and according to him there are various elements that impacts the source credibility of an endorser (Ahmad, Iqbal \& Farooq, 2014). The source credibility model suggests the effectiveness of the subject matter depends on the expertise and trustworthiness of the celebrity seemed by the customer (Ohanian, 1991). The source credibility model explains that success of the message depends on the level of expertise and trustworthiness that customers observed in a celebrity (Sternthal, Dholakia et al, 1978).
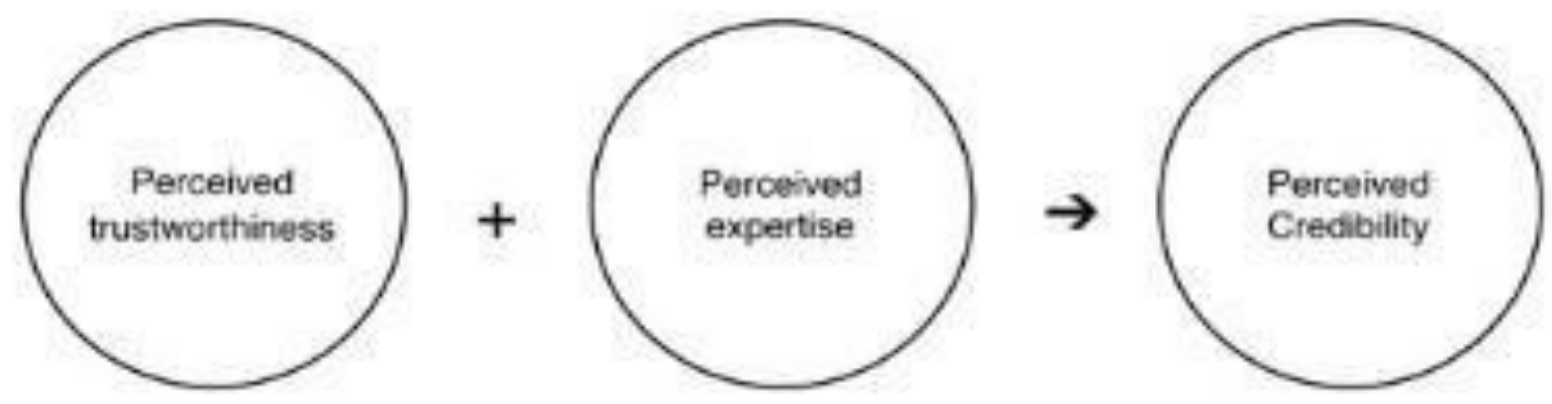

Expertise can be defined as;

"The extent to which the endorser is perceived to be knowledgeable, skillful and experienced". And it usually proves to be true (Hovland \& Weiss, 1951). Expert endorser gives the benefits like increasing brand remembrance and good impact on consumer's buying behavior (Erdogen, 1999). According to Zhang et al, (2011) the word 'fit' has a close relation with the word expertise as the sportsperson can proved to be more successful for the brand associated to the enactment of a sportsperson in a particular game. According to Ohanian (1991) the expertise observed in a celebrity is more convincing than attractiveness \& trustworthiness in order to enhance purchase intentions. Expert celebrity endorsers usually proved to be more convincing (Aaker and Myers, 1987) and can easily persuade the customer buying intention (Ohanian, 1991). Ohanian (1990) defined trustworthiness as;

"The listener's degree of confidence in, and level of acceptance of, the speaker and the message"

Trustworthiness can be defined as;

"The extent to which the endorser is perceived to be believable, honest and dependable".

If these characteristics are readily available in an endorser, there is greater chance to be hired by the marketers (Shimp, 2007). In the ratings of credibility, trustworthiness is most worthy in the eyes of customer because it's the non-physical trait that operates due to trust (Moynihan, 2004). The significant elements of the trustworthiness are reliability, dependable, honesty, sincere \& trustworthy. In the desire of following the trend by the celebrity endorsers, most of the adolescents are proved to be more dependable than their old generation (Pandey, 2011). 
A celebrity who possess all the main factors of credibility source could significantly enhance the buying behavior of customer (Liu et al, 2007). Companies could take benefit of highly credible celebrity that is the result of high repute, fame, high public image \& trustworthiness (Song, Chaipoopiratana et al, 2008). However research verified to have an important and direct impact on buying behavior of customers it can assist advertisers in choosing endorsers although it is not the single element to be considered in picking celebrities as endorsers (Erdogan, 1999).

H3: Endorser's credibility has a relation with consumer's purchase intentions.

\section{CELEBRITY VS NON-CELEBRITY ENDORSEMENT}

It's not just a chance that celebrity endorsement is the widespread application in advertising suite. Research shows that celebrity endorsers proved to be more efficient in affect than other type of endorsers like company employee, usual customer and the professional adept (Seno and Lukas, 2007). In order to ensure that the celebrities that are being used are exclusively endorsing a specific product, have more supervisory command over them. Companies can construct and enhance appeals that are compatible with their brand ethics and target customers. Contrary to this, celebrity endorsers has developed an identity \& personality of their own with the passage of time and company lost regulatory power over them (Tom et al, 1992).

Earlier studies on celebrity endorsement disclose that as compared to a non-celebrity endorser, celebrity endorsers has generated more affirmative behaviors in the direction of marketing and increased buying target (Atkin and Block 1983; Petty et al, 1983, Ohanian, 1991). On the other hand, Mehta (1994) claimed that there are no drastic variations in behaviors towards marketing, and buying behaviors regarding perception of a celebrity endorsed brand and a non-celebrity endorsed brand. Although, intellectual reaction of plaintiffs cause variation.

There were two distinctive researches has been done by Agrawal and Kanakura (1995) and Mathur, Mathur and Rangan (1997) in order to estimate the financial value of celebrity endorsement agreements on the anticipated productivity of a business. They have used event study methodology, with the help of which the assessment properties of advertising verdicts can be classified (Mathur et al, 1997). Unexpectedly, the results of both the studies proves the significance of the use of celebrity endorsers (Erdogan, 1999). McCraken (1989) explored that the celebrities use as endorsers are more appropriate method in order to transfer meaning to the brands because of the perception that celebrities adds their own symbolic meaning to the whole process of endorsement and cultural denotation of celebrity transferred from celebrity to product and then to the customer.

Messages notices by the customer from two distinctive brands in which one is a product endorsed by celebrity while the other is not, customers represents the higher purchase intentions towards the celebrity endorsed product (Clark \& Horstman, 2003). In a parallel evaluation, Celebrity endorsers proved to be more credible, skilled and even more beautiful than the non-celebrity endorsers (Atkin and Block, 1983). The study of perception of advertising and celebrity endorsement represents that content rating of the advertisement enhanced by using popular and famous celebrity as an endorser (Rashid and Nallamuthi, 2002).

Zoubi and Bataineh (2011) adds to the topic by concluding that there is no variation in celebrity and non-celebrity endorser's impact on customer's purchase intention. Hence its 
advice for the company to use famous celebrities and endorsers rather than unknown person, it will give company a competitive advantage and customers can distinguish products from that of opponents (Silvera and Austad, 2004).

H4: Advertising campaigns that contain celebrity endorsements have a higher relation with consumers purchase intentions than ad campaigns that do not perform with any celebrity.

\section{Single Vs Multiple Product \& Multiple Celebrity Endorsements}

We can categorized celebrity endorsement on the basis of number of products endorsed (single vs multiple products) and the number of celebrities (single vs multiple celebrities). If a celebrity endorsed only one product or brand then it is called single product endorsement. Subsequently, it's an exceptional case if celebrity endorsed a single product or brand usually celebrities prefer to endorse more than on product or brand (Nam-Hyun Um, 2008). Hsu and McDonald (2002) defined multiple celebrity endorsement as;

"The use of two or more celebrities in an advertising campaign".

He categorized multiple celerity endorsement, on the basis of how celebrities are presented in an advertisement, into two portions. In the first setup, for endorsement of a product two or more celebrities featured in an Ad. While in second scenario, the endorsement of the same product done by featuring different celebrities in a series of the Ad. In the industry of Marketing and advertisement, endorsing multiple celebrities is not a new sensation for advertisers. Some big brands like Nike, Adidas and American express are using this strategy.

Another significant example is Milk Mustache Campaign that featured almost 100 celebrities to promote milk since 1995 (Hsu and McDonald, 2002). For example there are many celebrities in India those had endorsed Pepsi brand like Sachin Tendulkar, Aamir Khan, Amitabh Bachan, Rahul Dravid, Shahid Kapoor, Kareena Kapoor, Ranbir Kapoor and Deepika Padukone etc (Khatri, 2006).

According to Hsu \& McDonald (2002) p.25,

"Multiple celebrity endorsement advertising may help the advertiser to build a sense of consensus, avoid audience boredom and appeal to multiple audience".

According to Cankaya University study, 72.5\% Turkish people prefer ads with multiple celebrities over Ads with single celebrity (Ergin and Akbay, nd)

People with this perception explains that multiple celebrity Ads shows that there is agreement regarding product or service's quality, hence "increasing the level of celebrity and persuasion" (Ergin and Akbay, 7). Erdogan and Baker (1999) claimed in their study that in order to endorse a particular brand, using multiple celebrities is most effective technique for the advertisers. Because by doing this they can influence and attract the whole target market. Although, featuring multiple celebrities in an Ad can also cause misperception regarding brand's uniqueness in customer's perception and hence it should be guaranteed that:

"Each and every celebrity possesses compatible meanings that are sought for brands" (Erdogan and Baker, 1999 p.13)

For example, L'Oreal endorses, its product line in relation to the characteristics of celebrity and meanings attached with them (Redenbach, 2005). If various celebrities are present in an advertisement, they complement each other in the process of meaning transmission to a 
product or brand (Sliburyte.L, 2009). Customer has a positive influence on behavior for the advertisement, behavior for brand and buying intentions when multiple celebrities are used in a campaign (Saleem, 2007). While contrary to this, Kasana and Chaudhary (2014) believes that it causes confusion among customers and causes hurdle in the process of meaning transfer if multiple celebrities use for brand endorsement.

In a study Redenbach (2005) claimed that it effects the celebrity's credibility and likeability if they endorses four different brands or products. And ultimately it loses uniqueness when celebrities concentrate on multiple brands rather than focus on one brand (Redenbach, 2005).

H5: Advertising campaigns featuring more than one celebrity endorsing the product, have a relation with consumers purchase intentions.

\section{Purchase Intentions Or Buying Behavior}

Tendency to buy a particular brand or product is known as purchasing intentions (Belch et al, 2004). Purchase intentions shows the probability that the person would purchase a product (Phelps and Hoy, 1996). Spears and Singh (2004) states that it's the sensible idea of doing struggle to buy a brand in future. It was an element of customer cognitive behavior on how customer planned to purchase a particular product, brand or service (Kwek, 2010). Perner (2009) defined consumer behavior as:

"The study of individuals, groups or organizations and the processes they use to select, secure, use and dispose of products, services, experiences or ideas to satisfy needs and the impacts that these processes have on the consumer and society".

Consumer's concern and anticipation in purchasing a product were the factors that can be used in the measurement of purchase intention. Like, customer's interest, attending, information and evaluation were the most concerned variables that decide the purchase intention (Laroche Zhou, 1996). Besides this, external components easily effects the customer's purchase intention in their decision making process. For example they can easily influenced by word of mouth and word of mouse communication while searching information. And their purchase intention can be influenced by products features, price and endorsers enactment perceived by customers during purchase process (Sheu, 2010). As, via promotion tactics the customer's purchase intentions stimulation can easily prompted, so their action in the direction of product ,brand or service which has been prompted can easily influenced by the fame and appearance of celebrity. Particularly when celebrities are seen as reference groups by customer, in order to feel prosperous, they wanted to copy them (Forbes,

2011). That's results in positive impact on customers buying behavior by their favorite celebrities (Pui yi \& Priscilla, 2012).

As Ajzen and Fishbein (1980, p.5) put it,

"Human beings are usually quite rational and make systematic use of the information available to them. People consider the implications of their actions before they decide to engage or not to engage in a given behavior".

Celebrity endorsement has a huge impact on purchase decision.

H6: Celebrities who endorse more than one product/brand at the same time have a relation with consumers purchase intentions 


\section{Research Design}

\section{METHODOLOGY}

The purpose of this research is to explore the impact of celebrity endorsement on consumer buying behavior, so the exploratory research has been undertaken. In an exploratory research, the relationship between variables has been established. So as to explain the relationship between variables, it highlight on analyzing the situation or problem (Saunders et al, 2009).

\section{Conceptual Framework}

The key purpose of this research is to find out the impact of celebrity endorsement on consumer buying behavior.

A conceptual framework was adopted, which is presented in Figure.1. It is designed in order to clearly understand the relationship between independent variables as related to dependent variable of the study. On the left hand side, there are present all the independent variables including gender, attractiveness, credibility, endorsement type (celebrity vs noncelebrity), multiple celebrity endorsement and multiple product endorsement. While on the right hand side the only single dependent variable 'consumer purchase intentions' is present.

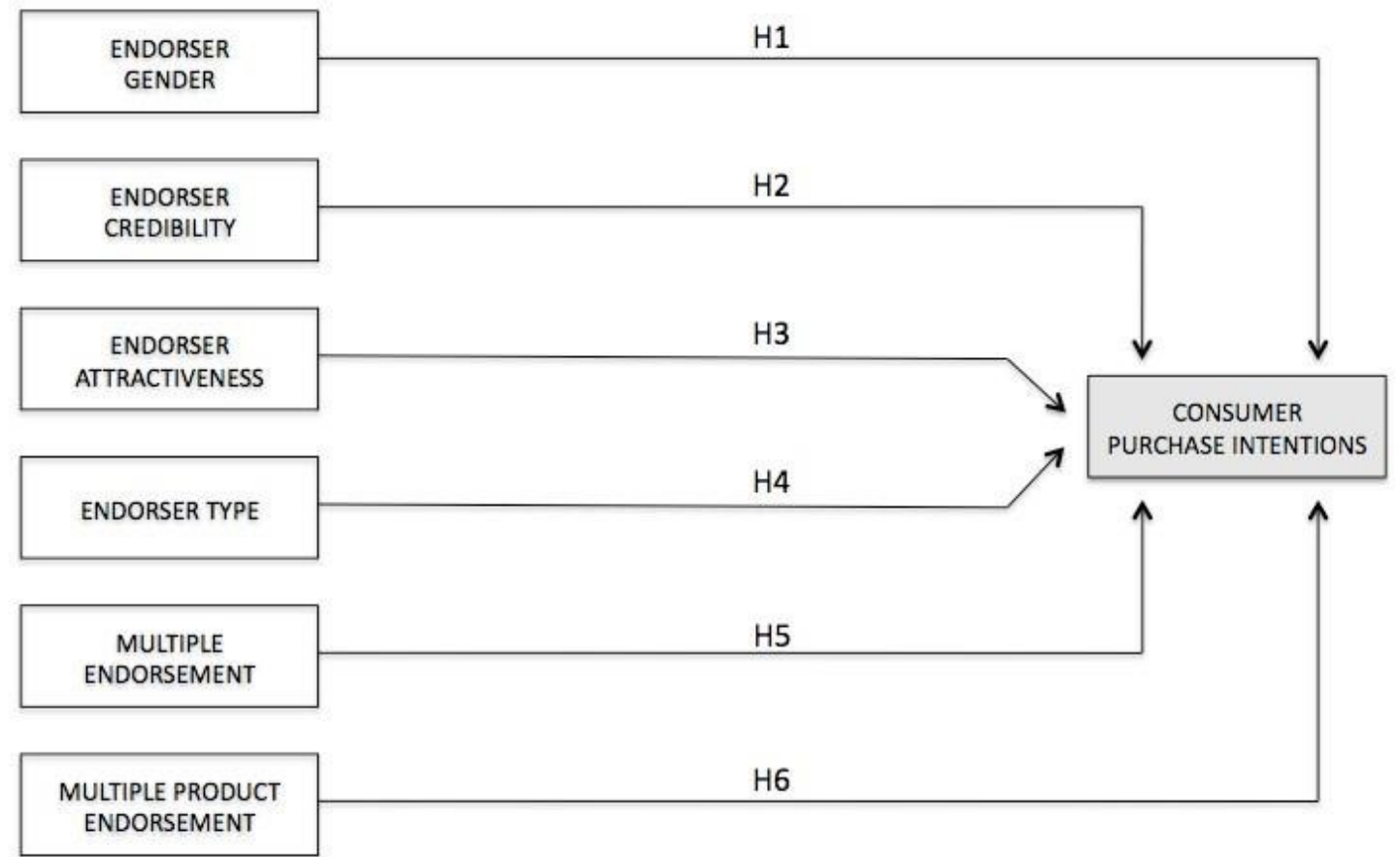

Figure.1

\section{Population}

All those individuals which are concerned in making statistical inferences is the target population (Henlal and Jentoft, 2011). So all the male and female individuals of Pakistan, over the age of 15 are included in the target population for the study.

\section{Sample}

A small part of something intended as representative of the whole population. 


\section{Sampling Technique}

According to Tustin, Ligthelm and Martinsn (2005), the alternative sampling is of two types' probability and non-probability sampling techniques. The sampling of this study consists of nonprobability and convenience sampling technique is being used.

\section{Sample Size}

The sample used for this study is mainly young Pakistani audience with educational background of high school, under graduate and Masters Degrees.

In this survey 165 individuals has participated. But some responders has not finished the questionnaire and some responses were invalid so it reduces the sample size to 150 . According to Sekaran (2003) that for most of the researches the sample size larger than 30 and less than 500 is suitable. So the sample used in this study is also considered appropriate.

\section{Data Collection}

It is important for a researcher to collect all the needed information and data from the relevant and representative people in order to gain desired outcomes. Primary data has been collected by using a structured questionnaire. The data was collected from the males and females enrolled in the department of Management Sciences of Islamia University of Bahawalpur and from some other high school and college students as well.

\section{Questionnaire}

A formalized set of questions that helps to take the necessary data from the responders is Questionnaire. It should explain the data requirement in the form of a particular questions that are easily understandable by the responders and they show willingness to answer (Malhotra, 2006).

The questionnaire is adopted and it contained 35 questions. Respondents were asked to rate their opinion on a five point Likert scale mentioning 1 as strongly agree and 5 as strongly disagree. Questionnaire was adopted from two different resources which are Carvalho, 2012 and Pui Yi, Priscilla, 2012.

\section{Response Rate:}

\section{DATA ANALYSIS, FINDINGS \& DISCUSSION}

For this particular study we deliver 165 questionnaires to the target population and among them we received 150 questionnaires. And we found all of them suitable enough for further analysis. Thus, the response rate comes to $90.91 \%$ as shown in the table: 1 .

\begin{tabular}{|l|l|l|}
\hline Questionnaire Delivered & Questionnaire Received & Response Rate \\
\hline 165 & 150 & $90.91 \%$ \\
\hline
\end{tabular}

Table: 1

Data was entered, edited and analyzed by using Software, SPSS version 19 by applying techniques of Frequency Distribution, Cronbach's Alpha \& Correlation. 


\section{Demographic Profile of Respondents:}

Table:2 Gender

\begin{tabular}{|c|c|c|c|c|}
\hline & & & & $\begin{array}{c}\text { Cumulative } \\
\text { Percent } \\
\text { Valid } \\
\text { Percent }\end{array}$ \\
& Frequency & Percent & \\
\hline $\begin{array}{c}\text { Valid } \begin{array}{c}\text { male } \\
\text { fomale }\end{array} \\
\end{array}$ & 62 & 41.3 & 41.3 & 41.3 \\
& 88 & 58.7 & 58.7 & 100.0 \\
& 150 & 100.0 & 100.0 & \\
\hline
\end{tabular}

This table depicts the gender demographic variable and illustrates that most of our respondents were females (58.7\%) with frequency of 88 out of 150 and remaining are male with (41.3\%) and frequency of 62 . Moreover, Bar Chart illustrates the dominance of female respondents.

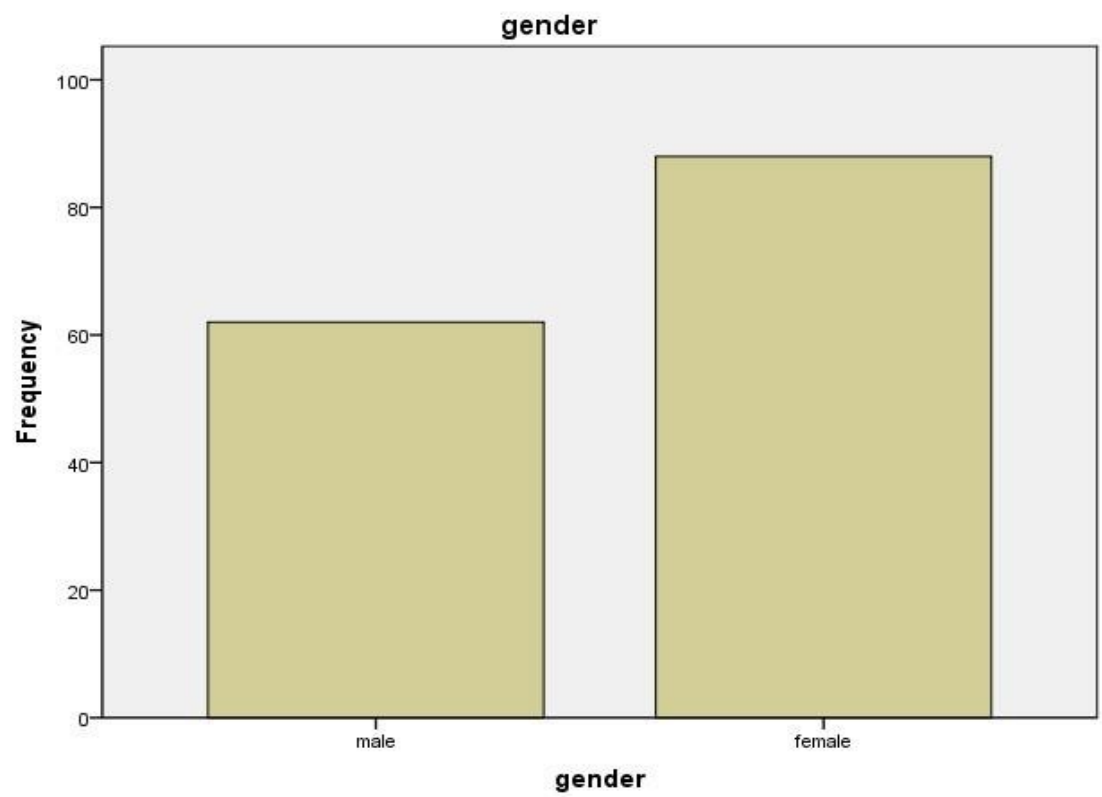


Table: 3

\begin{tabular}{|c|c|c|c|c|c|}
\hline \multicolumn{6}{|c|}{ age } \\
\hline & & Frequency & Percent & Valid Percent & $\begin{array}{l}\text { Cumulative } \\
\text { Percent }\end{array}$ \\
\hline \multirow[t]{5}{*}{ Valid } & $15-20$ & 22 & 14.7 & 14.7 & 14.7 \\
\hline & $21-25$ & 72 & 48.0 & 48.0 & 62.7 \\
\hline & $26-30$ & 46 & 30.7 & 30.7 & 93.3 \\
\hline & above 30 & 10 & 6.7 & 6.7 & 100.0 \\
\hline & Total & 150 & 100.0 & 100.0 & \\
\hline
\end{tabular}

This table shows the Age level demographic variable and shows that lot of respondents belong to the age bracket of (21-25) with (48\%) and frequency of 72 out of 150 . Respondents of age (15-20), (26-30) and (above 30) with percentages 14.7\%, 30.7\% and $6.7 \%$ and frequencies of $22,46 \& 10$ respectively out of 150 . Moreover Bar chart provides graphical representation of the age level of respondents.

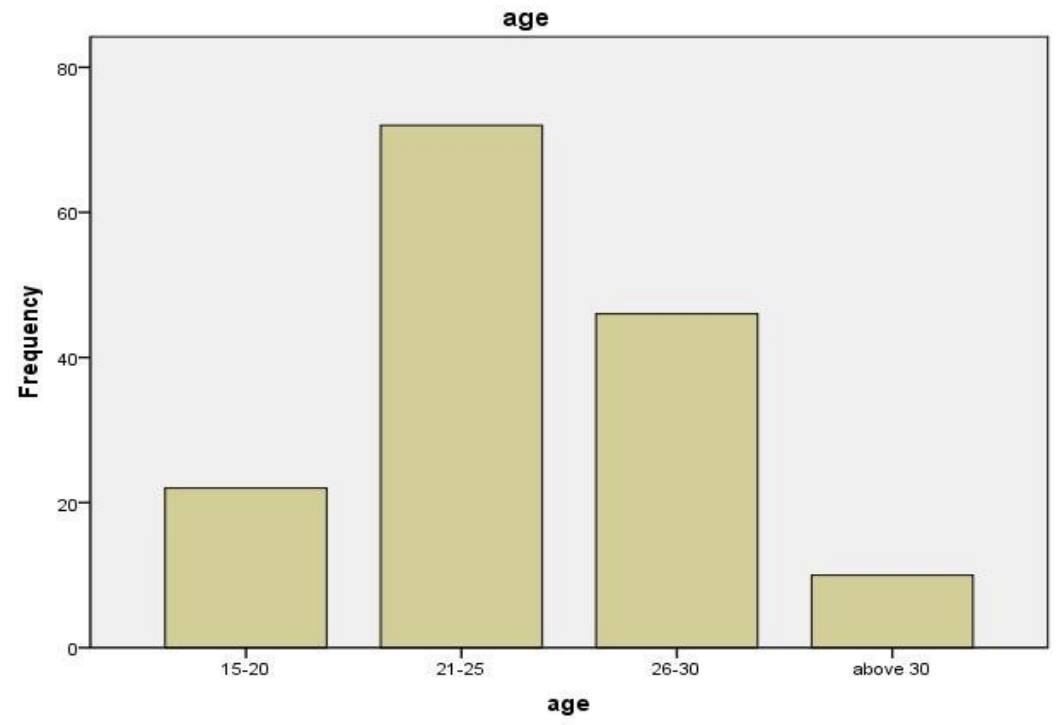

Table: 4: Educational Background

\begin{tabular}{|c|c|c|c|c|}
\hline & Frequency & Percent & $\begin{array}{l}\text { Valid } \\
\text { Percent }\end{array}$ & $\begin{array}{r}\text { Cumulative } \\
\text { Percent }\end{array}$ \\
\hline \multirow{2}{*}{$\begin{array}{l}\text { Valid matric } \\
\text { Inter }\end{array}$} & 4 & 2.7 & 2.7 & \multirow{6}{*}{$\begin{array}{l}2.7 \\
13.3\end{array}$} \\
\hline & 16 & 10.7 & 10.7 & \\
\hline \multirow{4}{*}{$\begin{array}{l}\text { Bachelor } \\
\text { Master } \\
\text { M.Phil./PhD }\end{array}$} & 58 & 38.7 & 38.7 & \\
\hline & 58 & 38.7 & 38.7 & \\
\hline & 14 & 9.3 & 9.3 & \\
\hline & 150 & 100.0 & 100.0 & \\
\hline
\end{tabular}


This table illustrates the qualification level demographic variable and depicts that lot of respondents are Bachelor and Masters with equal percentage of (38.7\%) and frequency of 58 and 58 respectively out of 150. Matric, Intermediate, and M.Phil. have 2.7\%, 10.7\%, and 9.3 percentages respectively and frequency with 4,16 and 14 respectively. It is clearly indicate that most of the respondents claimed to have a degree of Bachelors and Masters. Moreover Bar chart provides graphical representation of the qualification level.

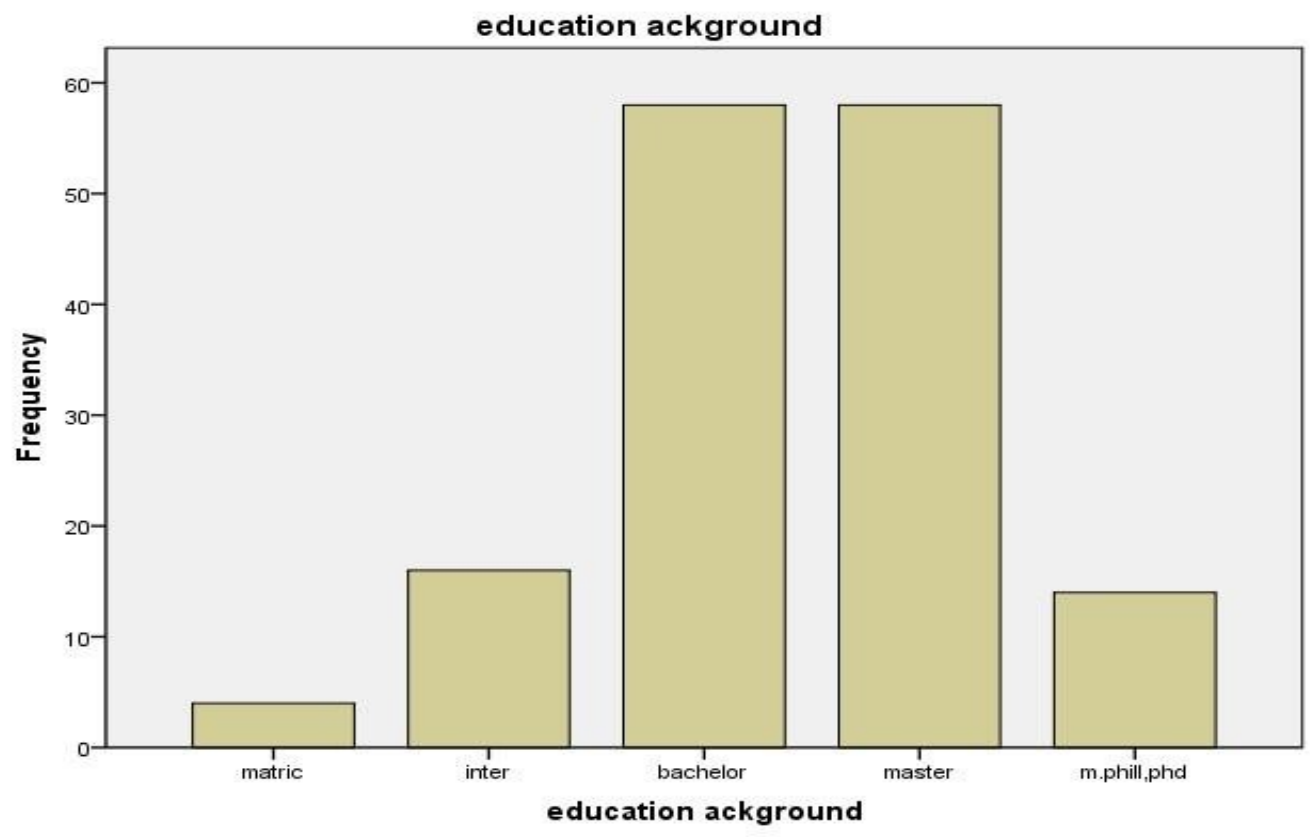

\section{Cronbach's Alpha}

To check the internal reliability of instrument, Cronbach's Alpha was run. The value of Cronbach's Alpha comes to 0.701. Which is above the standard value proposed by (Nunnally, 1978) of 0.70 and 0.60 by Moss et al, (1998). This shows that our instrument is reliable and we can confidently apply different statistical tests and interpret the results with confidence.

\section{Reliability Statistics}

\begin{tabular}{|c|l|c|}
\hline Cronbach's Alpha & & N of Items \\
\hline & .701 & 7 \\
\hline
\end{tabular}

\section{Correlation Analysis}

Pearson Correlation was run to check the relationship of variables with each other and whether any observed variable has perfect covariance with any other variables, which are observed in the study. We applied correlation to all the variables. All relationships were found significant at $\mathrm{p}$ value of 0.01 except the variable 'multiple product endorsement' in below Table 5.

First three variables gender, attractiveness and credibility show a positive and weak relationship thus leads to accepting the hypothesis, while other two variables (endorser type and multiple celebrity endorsement) show positive and moderate relationship results in the acceptance of hypothesis and finally the last relationship (multiple product endorsement) depicts the negative but very weak relationship with the dependent variable (consumer purchase intentions) so results in the rejection of the hypothesis. We discussed correlation results of each variable separately. In this case, results suggest that some variables are weakly and some are moderately but positively relate to the buying intentions of consumer except the 
'multiple product endorsement' which is weakly and negatively correlated with the consumers buying intentions as shown in the table below:

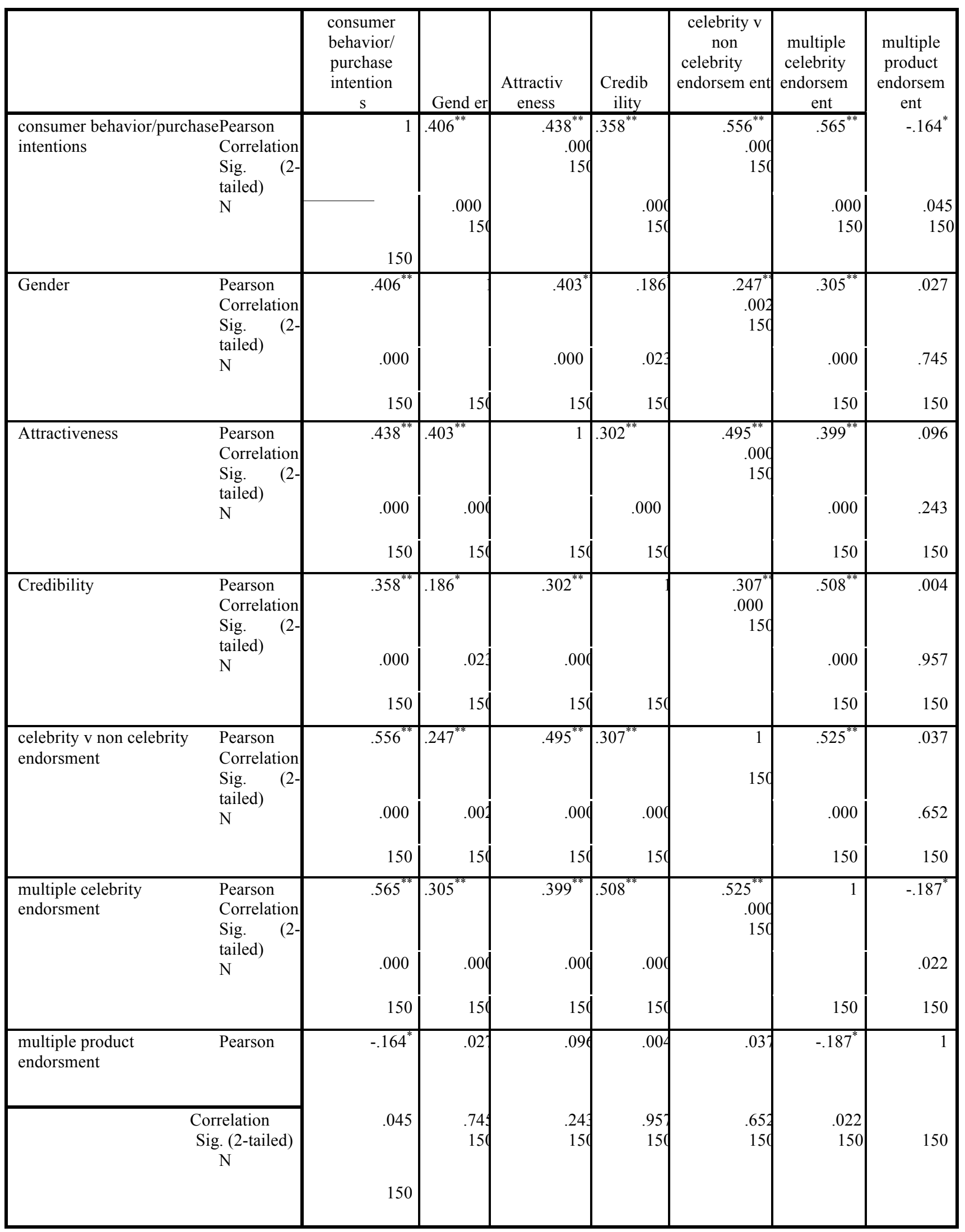

**. Correlation is significant at the 0.01 level (2-tailed).

*. Correlation is significant at the 0.05 level (2-tailed). 


\section{Summarized Results}

\begin{tabular}{|c|c|}
\hline HYPOTHESIS & $\begin{array}{c}\text { RESULTS \& } \\
\text { RELATIONSHIPS }\end{array}$ \\
\hline $\begin{array}{l}\text { H1: Endorser's gender has a } \\
\text { relation with consumers } \\
\text { purchase intentions. }\end{array}$ & Positive \& Weak \\
\hline $\begin{array}{l}\text { H2: Endorser's attractiveness has a } \\
\text { relation with customer purchase } \\
\text { intentions. }\end{array}$ & Positive \& Weak \\
\hline $\begin{array}{l}\text { H3: Endorser's credibility has a } \\
\text { relation with consumer's purchase } \\
\text { intentions. }\end{array}$ & Positive \& Weak \\
\hline $\begin{array}{l}\text { H4: Advertising campaigns } \\
\text { that contain celebrity } \\
\text { endorsements have a higher } \\
\text { relation with consumers } \\
\text { purchase intentions than ad } \\
\text { campaigns that do not perform } \\
\text { with any celebrity. }\end{array}$ & $\begin{array}{l}\text { Positive \& } \\
\text { Moderate }\end{array}$ \\
\hline $\begin{array}{l}\text { H5: Advertising campaigns } \\
\text { featuring more than one } \\
\text { celebrity endorsing the product, } \\
\text { have a relation with consumers } \\
\text { purchase intentions. }\end{array}$ & $\begin{array}{l}\text { Positive \& } \\
\text { Moderate }\end{array}$ \\
\hline $\begin{array}{l}\text { H6: Celebrities who endorse } \\
\text { more than one product/brand at } \\
\text { the same time have a relation } \\
\text { with consumers purchase } \\
\text { intentions. }\end{array}$ & Negative \& Weak \\
\hline
\end{tabular}

\section{Conclusion}

\section{CONCLUSION \& RECOMMENDATIONS}

Celebrity endorsement has totally change the old way of marketing used in previous years.

It is been accepted to be a "uiquititous feature of modern day marketing" (McCracken, 1989). Advertisements are always a mean to attract the attention of a consumer. In order to get enough attention by the audience marketers use different methods. Among which the use of celebrity endorser in advertisement is the most significant and widely practiced. Same as previous researches, this study also confirms the significance of celebrity endorser's use in advertisements as it positively impacts the consumer's purchase intentions.

This study was planned to examine that how different dimensions and attributes of celebrity endorsers (i.e., gender, attractiveness, credibility, endorser type, multiple celebrity endorsements \& multiple product endorsements) would impact a consumer's buying 
intentions. Correlation results indicate that there is a positive relationship between independents including gender, attractiveness, credibility, endorser type, multiple celebrity endorsements and the consumer's buying intentions with the value of $0.406,0.438,0.358$, $0.556 \& 0.565$ respectively, except multiple product endorsement that shows the negative relationship with consumer's buying intentions (dependent variable) by depicting the value ($0.164)$. Hence by considering the values of correlation all the hypothesis were accepted except $\mathrm{H}: 6$ which was rejected.

This study illustrates that the gender of an endorser positively impacts the buying behavior.

However relationship is weak that shows that customer's buying intentions are effected by the gender of endorser but to a low extent. The study suggests same about the attractiveness and credibility of celebrity endorser. That means if celebrity is attractive, trustworthy and expert it would enhance the purchase intentions of consumer but in a low tendency. As far as the celebrity vs non-celebrity endorsement and multiple celebrity endorsement is concerned, it effects the buying intentions of consumer more strongly as compared to other variables. But surprisingly the study illustrates the negative and weak relationship between multiple product endorsement by the celebrity and consumer's buying intentions. That shows when a celebrity endorse multiple products it negatively impacts the consumer's buying intentions and consumers would reluctant to buy such products. This study does not back and complement all the previous findings and results of the literature, but shows some similarities as well.

Responders approve the thought that a celebrity makes an ad more famous, memorable and consideration. That aligned with some previous studies, which illustrates that the content ranking of an ad is increased by using a famous celebrity (Rashid and Nallamuthu, 2002).

\section{RECOMMENDATIONS}

The study used was exploratory with convenient sampling so author does not claim the generalizability of the study and the results to be $100 \%$ accurate. As we know celerity endorsement is a very controversial and multidimensional topic. So it could not provide thorough findings in a single research. So there is always a room for further research. In future this study can be conducted by using other different variables. A large, diverse and representative sample size with various distinctive demographics can be tested in order to make the study more generalized. For further studies in future focus group can turn out to be supportive in order to explore the each and every dimension of consumer's thought, belief and behavior. For further research in addition with the quantitative analysis, qualitative approach can be used like interviews and focus groups would allow a researcher to take thorough responses that would enhance the understanding and knowledge of the research probes. There could be a study in future with other different variables and there should be more in-depth study in order to understand every variable more appropriately.

In a nutshell, celebrity endorsement is an active promoting instrument. The companies should focus on selecting the most appropriate celebrity endorser for their product in order to gain more attention and provoke the concern of consumer.

\section{Limitations}

Every study has some limitations, so it is essential to accept them before generalizing the results and giving any suggestions. The limitations of this study are: 
The sample is very small \& not enough to represent the whole population of Pakistan. So the study could not make concrete testimonials.

Majority of the respondents were students and young people so the result could not be generalized to the whole population.

All the responders taken from urban area by totally neglecting the rural response as they remain untouched.

The time and resources were limited for the study.

Research was based totally on quantitative approach and qualitative approach is being ignored.

The respondents do not fill the questionnaire with full concentration thus manipulate the results.

Sample was not derived from probability sampling but non-probability \& convenient sampling technique is used.

The study was only restricted to one city of Pakistan as all the respondents taken were from Bahawalpur.

In most of the cases responders have very limited knowledge regarding celebrity endorsement.

\section{References:}

CHOI, S. and N. J. Rifon (2007). "Who is the celebrity in advertising? Understanding dimensions of celebrity images." The Journal of Popular Culture 40(2): 304-32

Schlecht, C. (2003). "Celebrities impact on branding." Center on Global Brand Leadership, Columbia: Columbia Business School.

McCracken, G. (1989), “Who is the Celebrity Endorser? Cultural Foundations of the Endorsement Process”, Journal of Cons

Silvera, David H. and Austad, Benedikte. (2004), "Factors predicting the effectiveness of celebrity endorsement advertisements", European Journal of Marketing, Vol.38, No. 11/12

Friedman, H. and Friedman, L. (1979), "Endorser Effectiveness by Product Type”, Journal of Advertising Research, Vol.19, No.5.

Reginald Esangbedo, "THE IMPACT OF CELEBRITY ENDORSEMENTS ON THE BUYING BEHAVIOR OF ROWAN UNIVERSITY STUDENTS AGE 18-24" Rowan University, May 20, 2011.

Katyal, S., (2007). Impact of Celebrity Endorsement on a Brand, Chillibreeze writer, available at www.chillibreeze.com/articles/ accessed on 15th Jan, 2010.

Kambitsis, C., Harahousou, Y., Theodorakis, N., \& Chatzibeis, G. (2002). Sports advertising in print media: The case of 2000 Olympic games. Corporate Communications, 7(3), 155-161.

Temperley, John and Tangen, Daniel (2006), - The Pinocchio factor In Consumer Attitudes towards Celebrity Endorsement: Celebrity Endorsement, The Reebok Brand, And an Examination of a Recent Campaign \|, Innovative Marketing, Volume 2, Issue 3, and Special Edition on Consumer Satisfaction- Global Perspective

Lafferty, B. A. and R. E. Goldsmith (2004). "How Influential are Corporate Credibility and Endorser Attractiveness When Innovators React to Advertisements for a New High Technology Product?" Corporate Reputation Review 7: 24-36.

Loudon, D. \& Della, Bitta A. (1994) Consumer Behavior Application (4th ed). New York: McGraw Hill.

Aaker, David A. (1996), Building Strong Brands. New York, NY: The Free Press Jyoti Kasana, Naveen Chaudhary, International Research Journal Commerce arts science, Volume 5 Issue 2 (Year-2014) ISSN 2319-9202

Phang. Grace, De Run Ernest Cyril (2007). "Celebrity endorser and respondents gender: Its impact on company, behavioral and attitudinal variables", Journal of Humanities, Vol. 10, 38-55

Debevec, K. and J. B. Kernan (1984). "More Evidence On The Effects Of A Presenter's Attractiveness Some Cognitive, Affective, And Behavioral Consequences" Advances in Consumer Research 11: 127-132. 
Klaus, N. and Bailey, A. (2008), “Celebrity Endorsements: An Examination of Gender and Consumers Attitudes”, American Journal of Business, Vol.23, No.2.

Tom, G., Clark, C., Elmer, L., Grech, E., Masetti, J., Jr. \& Sandhar, H., (1992). The use of created versus celebrity spokespersons in advertisements. Journal of Consumer Marketing, 9, 45- 51.

Baker, M. \& Churchhill, G.A. (1977) the impact of physically attractive models on advertising evaluations. Journal of Marketing Research, 14(4), pp. 538-555.

Jain, A. and Patel, R. (nd) "Effectiveness of Celebrity Endorsers in Various Product Categories”, Journal of Marketing Trends, Vol.1, No.2.

Patzer, G.L, (1985). Research claims that beauty is wallet deep; Marketing News, (Aug), p30 Endorgan, B.Z., (1999). Celebrity Endorsement: A literature review. Journal of marketing management, 15, 291-314.

Bower, A. B. and S. Landreth (2001). "Is beauty best? Highs versus normally attractive models in advertising." Journal of Advertising 30: 1-11.

Caballero, M. J. and P. J. Solomon (1984). "Effects of Model Attractiveness on Sales Response." Jour

Kambitsis, C., Harahousou, Y., Theodorakis, N., \& Chatzibeis, G. (2002). Sports advertising in print media: The case of 2000 Olympic games. Corporate Communications, 7(3), 155-161.nal of Advertising 13: 17-23.

Deshpandé, R. and D. M. Stayman (1994). "A Tale of Two Cities: Distinctiveness Theory and Advertising Effectiveness." Journal of Marketing Research 31: 57-64.

Amos, C., Holmes, G and Strutton, D (2008), "Exploring the relationship between celebrity endorser effects and advertising effectiveness", International Journal of Advertising, 27(2), pp. 209-234

Hovland, I., \& Weiss, W. (1951). The Influence of Source Credibility on Communication Effectiveness. Public Opinion Quarterly 15(4), 635-650.

Ohanian, R. (1991), “The impact of celebrity spokespersons' perceived image on consumers' intention to purchase", Journal of Advertising Research, Vol. 31 No. 1, pp. 4654.

Aronson, E., Turner, J.A., Carlsmith, J.M (1963). Communicator credibility and communications discrepancy as determinants of attitude change. Journal of abnormal and social psychology, 67 (July), 31-36.

Lutz, R.J., MacKenzie, S.B., and Belch, G.E. (1983), "Attitude toward the Ad as a mediator of Advertising Effectiveness: Determinants and Consequences," 532-9 in Bagozzi, R.P.and Tybout, A.M. (eds.), Advances in Consumer Research, Vol. X, (Ann Arbor, MI: Association for Consumer Research)

Sternthal, B., R. Dholakia, et al. (1978). "The Persuasive Effect of Source Credibility: Tests of Cognitive Response." Journal of Consumer Research 4: 252-260.

Shimp, T. A. (2000). Advertising Promotion: Supplemental Aspects of Integrated marketing Communications. Fort Worth, TX, Dryden Press.

Moynihan, R. (2004). "The Intangible Magic of Celebrity Marketing." PLoS Medicine 1(1):102-104.

Patel PC. Impact of celebrity endorsement on brand awareness. IFCAI Journal of Management, 2009

Aaker, D.A. and Myers, J.G, (1987). Advertising management. 3rd Edition. London: Prentice Hall International

Liu, M. T., Y.-Y. Huang, et al. (2007). "Relations among attractiveness of endorsers, matchup, and purchase intention in sport marketing in China." Journal of Consumer Marketing 24: 358365.

Seno, D \& Lukas B.A. (2007), the equity effect of product endorsement by celebrities: A conceptual framework from a co-branding perspective, European Journal of Marketing, Publisher: Emerald Group Publishing Limited, Vol.41, No.1/2, pp.121-134.

Smith, E.G., Meurs, L. V., and Neijens, P.C. (2006) "Effects of Advertising Likeability: A 10Year Perspective". Journal of Advertising Research, 46, 1 (2006): 73-83.

Aaker, D.A., (1996)"Building strong brands ". New York: The Free Press.

Ajzen, I., \& Fishbein, M. (1980). "Understanding attitudes and predicting social Behavior". Toronto, Ontario: Prentice-Hall.

Atkin, C. and Block, M., (1983). Effectiveness of Celebrity Endorsers. Journal of Advertising Research, 23, March, pp.57-61. 
Mehta, A., (1994). How advertising response modelling (ARM) can increase ad effectiveness, Journal of Advertising Research, Vol. 34, Issue. 3, pp. 62-74.

Agrawal, Jagdish, and Wagner A. Kamakura. "The Economic Worth of Celebrity Endorsers: An Event Study Analysis." Journal of Marketing (1995): 56-62. Fuqua School of Business. Duke University. Web. 20 Jan. 2011.

<http://faculty.fuqua.duke.edu/ kamakura/My\%20Reprints/the\%20economic\%20worth\%20of\% 20celebrity\%20endorsements.pdf>.

Mathur, L.K, Mathur, L., and Rangan, N., (1997). "The wealth effects associated with a celebrity endorser: The Michael Jordan phenomenon," Journal of Advertising Research, 37 (May/Jun), 67.

McCracken, G. (1989), "Who is the Celebrity Endorser? Cultural Foundations of the Endorsement Process", Journal of Consumer Research, Vol.16, No.3.

Atkin, C. and Block, M., (1983). Effectiveness of Celebrity Endorsers. Journal of Advertising Research, 23, March, pp.57-61

Rashid, Md., Nallamuthu, J. and Sidin, S., (2002), “Perceptions of Advertising and Celebrity Endorsement in Malaysia”, Asia Pacific Management Review, Vol.7, No.4, pp. 535-554.

Al Zoubi, M. and Bataineh, M. (2011), "The Effect of using Celebrities in Advertising on the Buying Decision "Empirical Study on Students in Jarash Private University", American Journal of Scientific Research, Issue 13, pp.59-70.

Um, Nam-Hyun (2008), "Exploring the Effects of Single vs. Multiple Products and multiple Celebrity Endorsements", Journal of Management and Social Sciences, Vol.4, No.2, pp.104-114.

Hsu, C.K. and McDonald, D., (2002). An examination of multiple celebrity endorsers in advertising. Journal of Product and Brand Management, Vol. 11 No. 1, pp. 19-28.

Khatri, Puja (2006), “Celebrity Endorsement: A Strategic Promotion Perspective”, Indian Media Studies Journal, Vol.1, No.1 July-Dec

Au-Yeung Pui Yi, Priscilla (2012), thesis on "EFFECTS OF CELEBRITY ENDORSEMENT ON CONSUMER PURCHASING INTENTION OF APPAREL PRODUCTS” Institute of Textiles \& Clothing, The Hong Kong Polytechnic University.

Wilson Edzorna Dzisah Chosniel Elikem Ocloo,(2013) “Celebrity Endorsement and Consumer Buying Behavior; Enhancing the Promotion Function of Marketing in the Central Business Area of Accra, Ghana, European Journal of Business and Management, ISSN 2222-1905 (Paper) ISSN 2222-2839 (Online),Vol.5, No.25, 2013

Ali Ahmed, Farhan Azmat Mir and Omer Farooq (2012), "EFFECT OF CELEBRITY ENDORSEMENT ON CUSTOMERS' BUYING BEHAVIOR; A PERSPECTIVE FROM PAKISTAN” INTERDISCIPLINARY JOURNAL OF CONTEMPORARY RESEARCH IN BUSINESS, Institute of Interdisciplinary Business Research, SEPTEMBER 2012.VOL 4, NO 5

Amit Kumar, (2010), “CELEBRITY ENDORSEMENTS AND ITS IMPACT ON CONSUMER BUYING BEHAVIOUR” The Executive Business School, Bournemouth University.

Anmol Randhawa and Javeed Ahmed Khan, (2014), "Impact of Celebrity Endorsement on Consumer Buying Behavior" International Journal of Business Management, ISSN No.:2349- 3402, Vol. 1(2), 2014

Zenit Raval \& Dushyant Tanna, (2014), "IMPACT OF CELEBRITY ENDORSEMENT ON BRAND BUILDING AND CONSUMER BUYING BEHAVIOUR” Int. J. Appl. Res. Eng. Sci., 2014, 1(4), 32-39

Redenbach, A., (2005). A Multiple Product Endorser Can Be A Credible Source. CyberJournal of Sport Marketing. ISSN. 1327-6816 Griffith University

Sliburyte, L. (2009). "How celebrities can be used in advertising to the best advantage?" World Academy of Science, Engineering and Technology 58: 934-939

Saleem, Flarida. (2007), "Effect of Single Celebrity and Multiple Celebrity Endorsement on Low Involvement and High Involvement Product Advertisements", European Journal of Social Sciences, Vol.5, No.3.

Ergin, Elif A., and Handan O. Akbay. The Effects of Single vs. Multiple Celebrity Endorsements towards Consumers' Purchase Intentions. Cankaya University, 2010. Web. 20 Jan. 2011. <http://www.marketing-trendscongress.com/2010_cp/Materiali/Paper/Fr/Akagun\%20Ergin_Ozdemir\%20Akbay.pdf>. 
Belch, G.E., and Belch, M.A. (2008), Advertising and Promotion: An Integrated Marketing Communication Perspective. (6th Ed.) New York. Irwin

Spears, N., \& Singh, S.N. (2004). Measuring attitude towards the brand and purchase intentions. Journal of current issues and research in advertising, 26(2), 53-556.

Kwek C.L (2010). The Effects of Shopping Orientations, Online Trust and Prior Online Purchase Experience toward Customers' Online Purchase Intention. International Business Research Vol. 3, No. 3

Laroche, M., Kim, C. and Zhou, L. (1996) 'Brand familiarity and confidence as determinants of purchase intention: an empirical test in a multiple brand context, Journal of Business Research, 37(2), 115-120.

Sheu, J. B. (2010), A hybrid dynamic forecast model for analyzing celebrity endorsement effects on consumer attitudes, Mathematical and Computer Modelling, 52 (9), 1554-156

Belch, G.E., and Belch, M.A., (2001). Advertising and Promotion: An integrated Marketing Communications Perspective (5th Ed.). Boston: Irwin/MaGraw- Hill. 